Génét. Sél. Evol., 1988, 20 (2), 259-266

\title{
Note
}

\section{Selection for increased and decreased total number of young born in the first three parities in mice}

\author{
Yolanda BAYON, L.F. FUENTE and F. SAN PRIMITIVO \\ Departamento de Producción Animal, Universidad de León, León, Spain
}

\begin{abstract}
Summary
A selection experiment carried out in mice for increased $\left(L^{+}\right)$and decreased $\left(L^{-}\right)$total number of young born alive in the first three parities $(T N Y-3)$ had been started in our laboratory. Data from the first 8 generations (reported by Fuente \& SAN Primitivo, 1985) showed considerable responses for upward and downward selection. In the present article, results obtained for generations $9-13$ are described. Realized heritability in the $L^{+}$line showed a gradual decline through generations, the value obtained for generations 9-13 $(0.16 \pm 0.04)$ being considerably lower than that estimated in the first 8 generations by Fuente \& SAN Primitivo (1985) $(0.24 \pm 0.03)$. No response was detected in the $L^{-}$line in this second period and a reversion towards the control line mean $(C)$ occurred. After 13 generations of selection, cumulated response, measured as a deviation from the control line, was 5.09 young in $L^{+}$and -2.11 young in $L^{-}$. Means for 1st, 2nd and 3rd litter size in generation 13 were $11.89,11.11$ and 11.63 young in $L+$, $11.03,10.42$ and 9.24 young in $C$ and $10.08,8.87$ and 9.06 young in $L^{-}$, respectively. Means for 6week body weight in generation 13 were $32.57 \mathrm{~g}, 32.38 \mathrm{~g}$ and $29.44 \mathrm{~g}$ in $L^{+}, C$ and $L^{-}$, respectively.
\end{abstract}

Key words : mice, litter size, selection.

Résumé

Sélection divergente sur le nombre total de jeunes nés dans les trois premières portées chez la souris

Une expérience de sélection a été conduite sur des souris dans notre laboratoire afin d'augmenter (dans la lignée $L^{+}$) et de diminuer (dans la lignée $L^{-}$) le nombre total de jeunes nés vivants dans les trois premières portées $(T N Y-3)$. Les observations faites sur les huit premières générations (décrites par Fuente \& SAN Primitivo, 1985) mettaient en évidence d'importantes réponses à la sélection dans les deux lignées. L'objet du présent article est de décrire les résultats obtenus sur les générations 9 à 13. L'héritabilité réalisée dans la lignée $L^{+}$a graduellement diminué au cours des générations, la valeur obtenue dans les générations 9 à $13(0,16 \pm 0,04)$ étant considérablement inférieure à celle estimée dans les huit premières générations par FUENTE $\&$ SAN Primitivo $(1985)(0,24 \pm 0,03)$. Aucune réponse n'a été détectée dans la lignée $L^{-}$au cours de cette seconde période et un retour vers la moyenne de la lignée témoin $(C)$ a été observé. Après 13 générations de sélection, la réponse cumulée, mesurée par la déviation par rapport à la lignée témoin, était de 5,09 jeunes dans la lignée $L^{+}$et de $-2,11$ jeunes dans la lignée $L^{-}$. Dans la $13^{\mathrm{e}}$ génération, les tailles moyennes des premières, deuxièmes et troisièmes portées étaient respectivement de 11,$89 ; 11,11 ; 11,63$ dans la lignée $L^{+}, 11,03 ; 10,42$ et 9,24 dans la lignée $C$ et 10,$08 ; 8,87$ et 9,06 dans la lignée $L^{-}$. Dans cette génération, le poids moyen à six semaines était respectivement de $32,57 \mathrm{~g}, 32,38 \mathrm{~g}$ et $29,44 \mathrm{~g}$ dans les lignées $L^{+}, C$ et $L^{-}$.

Mots clés : souris, taille de portée, sélection. 


\section{Introduction}

Despite the low heritability estimates, selection for first litter size in mice has generally led to considerable response, partly due to its high phenotypic variation (FAlCONER, 1960 ; BradFord, 1968 ; JoAKIMSEN \& BAKER, 1977 ; EISEN, 1978 ; BaKKeR et al., 1978).

A selection experiment based on the total number of young born in the first three litters $(T N Y-3)$ had been started in our laboratory and results from the first 8 generations (FUENTE \& SAN PRIMITIvo, 1985) had shown considerable responses for upward and downward selection. Responses obtained for generations 9-13 are reported in the present paper. Correlated responses in reproduction and growth traits are also described.

\section{Materials and methods}

Three lines had been derived from a randombred population of mice. Two of these were divergently selected for large $\left(L^{+}\right)$and small $\left(L^{-}\right)$reproduction rate, the selection criterion being the total number of young born alive in the first three parities $(T N Y-3)$. The third line $(C)$ served as an unselected control. Selection was carried out over 13 generations on the basis of individual performance for females only (litter size was considered a trait of the dam), males being randomly chosen. Breeding procedures and estimating of genetic parameters have been described by FuENTE \& SAN Primitivo (1985).

\section{Results}

Divergence between lines $L^{+}$and $L^{-}$did not increase through generations 9-13 by contrast to results obtained for generations 1-8 (FUENTE \& SAN PRIMITIVo, 1985), mainly due to the lack of response for downward selection.

\section{A. Selection differential and direct response}

Realized selection differentials $(S D r)$ in the $L^{+}$and $L^{-}$line in each generation as well as cumulative $S D r$ for divergence are presented in table 1 . The average $S D r$ obtained for the divergence for generations 9-13 (10.6 mice per generation) was slightly higher than that estimated by FUENTE \& SAN PRIMITIvo (1985) for generations 1-8 (8.9 mice per generation). After 13 generations of selection the expected selection differential $(S D e)(69.03)$ was nearly equal to realized selection differential (68.96) in $\mathrm{L}^{+}$, whereas $S D e(-60.03)$ was larger than $S D r(-55.61)$ in $L^{-}$. 
TABLE 1

Realized selection differential (SDr) and response (R) for TNY-3 (total number of young born in the first 3 parities)

\begin{tabular}{c|r|r|r|r|r|r}
\hline \hline \multirow{2}{*}{ Generations } & \multicolumn{2}{|c|}{ Line $L^{+}$} & \multicolumn{2}{c|}{ Line $L^{-}$} & \multicolumn{2}{c}{ Divergence } \\
\cline { 2 - 7 } & \multicolumn{1}{|c|}{$S D r$} & \multicolumn{1}{c|}{$R$} & \multicolumn{1}{c|}{$S D r$} & \multicolumn{1}{c}{$R$} & \multicolumn{1}{c}{$S D r^{*}$} & \multicolumn{1}{c}{$R^{*}$} \\
\hline \multirow{2}{9}{} & 3.93 & -2.60 & -4.45 & -2.23 & 79.85 & 6.88 \\
10 & 4.45 & 3.90 & -5.15 & 2.58 & 89.85 & 8.20 \\
11 & 7.74 & -1.48 & -3.85 & 0.56 & 101.04 & 6.16 \\
12 & 6.44 & 1.79 & -3.66 & 1.28 & 111.14 & 6.67 \\
13 & 7.05 & -0.33 & -6.38 & -0.86 & 124.57 & 7.20 \\
$1-8^{*}$ & 39.35 & 3.80 & -32.12 & -3.44 & 71.47 & 7.25 \\
$9-13^{*}$ & 29.61 & 1.61 & -23.49 & 1.33 & 53.10 & -0.05 \\
$1-13^{*}$ & 68.96 & 5.09 & -55.61 & -2.11 & 124.57 & 7.20 \\
\hline
\end{tabular}

$\left(^{*}\right)$ Cumulative.

After 13 generations of selection, means for $T N Y-3$ (estimated only for females that produced 3 litters in 85 days) were $34.73,29.64$ and 27.53 mice in $L^{+}, \mathrm{C}$ and $L^{-}$, respectively. The differences among the lines were statistically significant.

Responses to upward and downward selection as well as cumulative response for divergence are presented in table 1 for generations 9-13. Responses in $L^{+}$and $L^{-}$ measured as deviations from the control line showed large variability over generations and in many cases negative responses were observed. Direct response in $L^{+}$as deviation from $C$ showed the highest value in generation 12 (5.41 mice), that response being 5.09 mice after 13 generations of selection. No response was detected in $L^{-}$ through generations 9-13. On the contrary a reversion towards the control line mean was observed, the difference between $C$ and $L^{-}$being 2.11 mice in generation 13. After 13 generations of selection direct response for the divergence was 7.20 mice.

Realized heritabilities obtained for the two different periods are presented in table 2. Realized heritability in the $L^{+}$line showed a gradual decline through generations, the value estimated for generations $1-13$ being $0.18 \pm 0.03$. Realized heritability for generations $9-13(0.16 \pm 0.04)$ was lower than the corresponding value obtained by Fuente \& SAN Primitivo (1985) in generations $1-8(0.28 \pm 0.05)$. In the $L^{-}$line no response was observed through generations 9-13, the realized heritability for that second period showing a negative value.

TABLE 2

Realized heritabilities for TNY-3 (total number of young born in the first 3 parities)

\begin{tabular}{c|c|c|c}
\hline \hline Generations & Line $L^{+}$ & Line $L^{-}$ & Divergence \\
\hline $1-8$ & $0.28 \pm 0.05$ & $0.21 \pm 0.05$ & $0.24 \pm 0.03$ \\
$9-13$ & $0.16 \pm 0.04$ & $(-)^{*}$ & $(-)^{*}$ \\
$1-13$ & $0.18 \pm 0.03$ & $0.06 \pm 0.03$ & $0.12 \pm 0.02$ \\
\hline
\end{tabular}

$\left(^{*}\right)$ Negative value. 


\section{B. Correlated responses to selection}

\section{First, second and third litter size}

Means for first $(F L S)$, second (SLS) and third (TLS) litter size in $L^{+}, C$ and $L^{-}$ measured in generation 13 are depicted in figure 1 . Mean values for $1 \mathrm{st}$, 2nd and $3 \mathrm{rd}$ litter size in $L^{+}(11.89,11.11$ and 11.63 mice, respectively) were larger than the corresponding values in $L^{-}(10.08,8.87$ and 9.06 mice, respectively), differences being statistically significant. Means for $F L S, S L S$ and $T L S$ in the control line in generation 13 were $11.03,10.42$ and 9.24 young, respectively. Differences between such values and those of the selected lines reached statistical significance only for some of the traits mentioned.

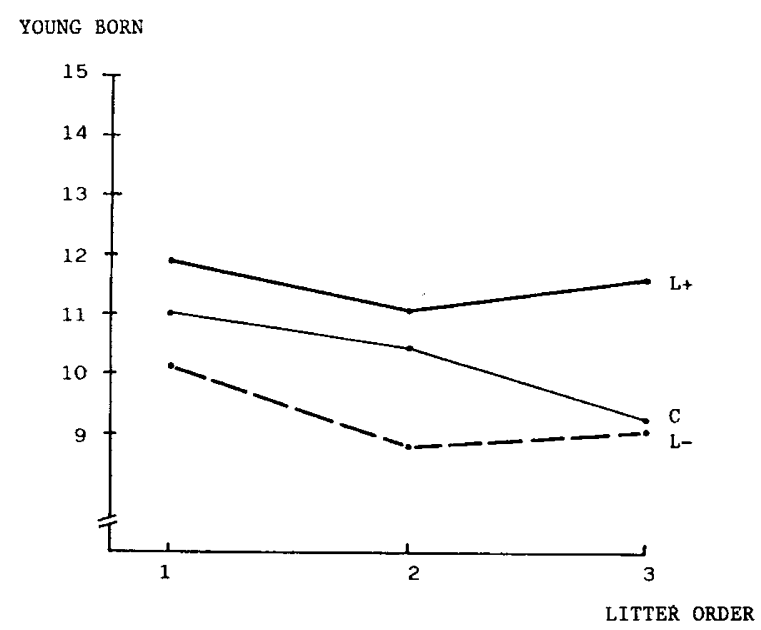

FIG. 1

Means for first, second and third litter size in $\mathrm{L}^{+}, \mathrm{C}$ and $\mathrm{L}^{-}$line in generation 13.

Correlated responses in each generation for divergence between $L^{+}$and $L^{-}$lines in $F L S, S L S$ and $T L S$ through generations 9-13 are shown in table 3. In generation 13 correlated responses for the divergence were $1.81,2.24$ and 2.57 mice for $F L S, S L S$ and $T L S$, respectively.

TABLE 3

Correlated responses in each generations for divergence between $\mathrm{L}^{+}$and $\mathrm{L}^{-}$in first (FLS), second (SLS), and third (TLS) litter size, 3-week (3-W) and 6-week (6-W) body weight

\begin{tabular}{c|c|c|c|c|c}
\hline \hline Generations & $F L S$ & $S L S$ & $T L S$ & $3-W$ & $6-W$ \\
\hline 9 & 2.25 & 2.83 & 1.64 & 0.67 & 1.33 \\
10 & 3.69 & 2.38 & 2.85 & 0.64 & 1.53 \\
11 & 1.72 & 1.94 & 2.31 & 1.20 & 1.79 \\
12 & 2.85 & 2.67 & 1.63 & 1.51 & 2.52 \\
13 & 1.81 & 2.24 & 2.57 & 1.57 & 3.13 \\
\hline \hline
\end{tabular}




\section{Body weight}

Correlated responses in 3-week and 6-week weight for the divergence between $L^{+}$ and $L^{-}$are presented in table 3 for generations 9-13. A small but consistent difference in body weight was detected between $L^{+}$and $L^{-}$in that period of selection. The difference increased slowly and reached the highest value in generation 13 . Regression of the divergence between the high and low lines on generations (for generations 9-13) showed an average increase per generation of $0.38 \pm 0.076 \mathrm{~g}$ and $0.45 \pm 0.044 \mathrm{~g}$ for 3week and 6-week body weight, respectively.

Means for 3-week and 6-week body weight in the $L^{+}, C$ and $L^{-}$lines measured in generation 13 are graphed in figure 2. Body weight at weaning ( 3 weeks) showed significant differences in generation 13 among the $L^{+}(14.21 \mathrm{~g}), C(13.54 \mathrm{~g})$ and $L^{-}$ $(12.64 \mathrm{~g})$ lines. Six week body weight in $L^{+}(32.57 \mathrm{~g})$ was significantly larger than in $L^{-}$ $(29.44 \mathrm{~g})$. However, the former value did not significantly deviate from that of the control line $(32.38 \mathrm{~g})$.

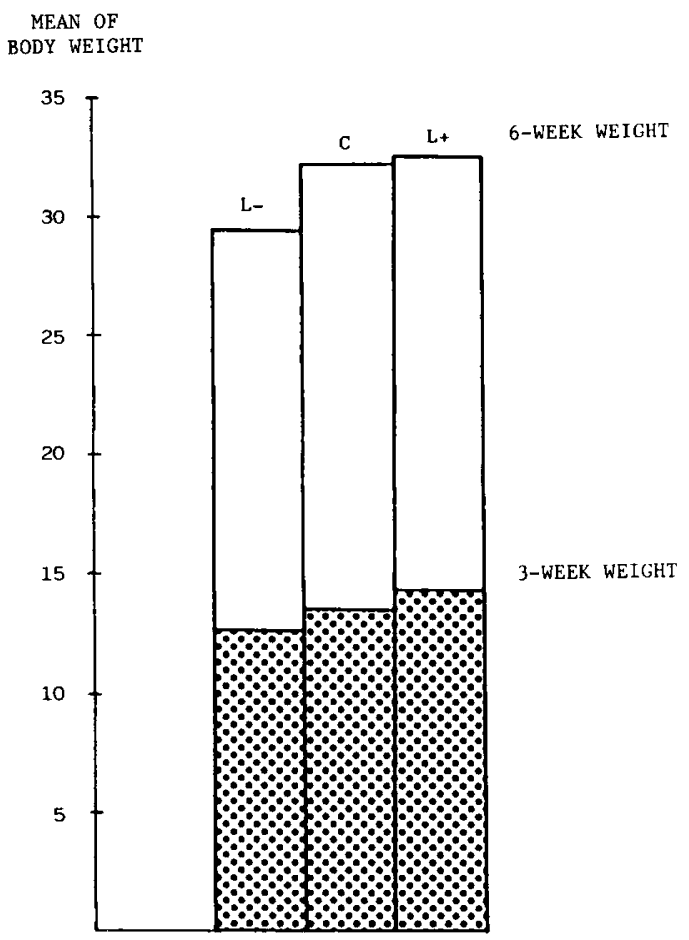

FIG. 2

Means for 3-week and 6-week body weight in $\mathrm{L}^{+}, \mathrm{C}$ and $\mathrm{L}^{-}$line in generation 13. 


\section{Discussion}

\section{A. Direct response}

Direct response in $L^{+}$through generations 9-13 was lower than in the first period (generations 1-8). It is generally accepted that litter size is a trait with little additive genetic variation. On the other hand a considerable response had been obtained in the first period of selection by Fuente \& San Primitivo (1985). It seems probable that little additive genetic variation was left, which explains the lower response obtained in generations 9-13 compared to generations 1-8.

However results indicated that response for increased TNY-3 although not high was maintained until generation 13 by contrast with results reported when selection was based on data of several litters in pigs (Ollivier, 1982 ; VANGEN, 1981) and in rabbits (Matheron \& Poujardieu, 1984). Standardization of litter size in laboratory animals seems to be one of the reasons for the different results obtained between laboratory and farm animals. That practice which is usual in experiments with mice avoids the negative covariance between litter size of daughter and dam (VANGEN, 1981). SKJERvoLD (1979) suggested that attempts could be made in pigs by standardizing litter size, where the animals removed from large litters would be raised by artificial feeding.

No response was detected for downward selection in our experiment through generations 9-13. Reduction of the additive genetic variation probably contributed to that result. On the other hand cessation of response might have been partially derived from the selection procedures for $T N Y-3$. Since only females that had given three litters within a period of 85 days were considered for selection, an indirect selection for improved fertility was performed both in the high and low line.

The relationships between litter size and other fertility traits are not well known. Bradford et al. (1980) and BARKLEY \& BRADFord (1981) observed an increased regularity of the cycle in a line of mice in which litter size was improved, whereas the line selected for small litter size showed a high percentage of irregular cycles and periods of anestrus. Moreover, LAND et al. (1973) found a positive correlation between increased ovulation rate and the duration of estrus in sheep and DaLTON \& RAE (1978) reported (in a general review) a high genetic correlation between estrus occurrence and the total number of lambs born per ewe over the first three lambings. All these results suggest that indirect selection for high fertility in the $L^{-}$line may have been opposing the selection for decreased $T N Y-3$.

\section{B. Correlated responses to selection}

\section{First, second and third litter size}

WALLINGA \& BAKKER (1978) found that females selected for first litter size showed a decrease in the size of the 2 nd, 3rd and following litters below the control line. That result was attributed to an effect of overloading in the uterus caused by shorter litter intervals combined with large litter size in the selected line. Results described by SCHÜLER \& BüNGER (1982) and LuXford \& BEILHARZ (1982), also indicate that overall lifetime reproduction is reduced following selection for first litter size. 
Selection for increased $T N Y-3$ resulted in a moderate response in 1st litter size. However, the superiority of $L^{+}$to the $C$ and $L^{-}$lines was maintained for the 2 nd and 3rd litter size. It seems then that under permanent breeding, decrease in reproductive performance with litter order is slower in females selected for increased $T N Y-3$ than in those selected for increased first litter size. As suggested by BEILHARZ \& LuXForD (1981), selection for traits closest to overall reproduction will probably be most useful in order to increase reproduction rate.

\section{Body weight}

Divergent selection for $T N Y-3$ resulted in differences in 3-week and 6-week body weight between the $L^{+}$and $L^{-}$line, although those differences were not large. The average increase in body weight divergence between $L^{+}$and $L^{-}$per generation showed a larger value for generations $9-13(0.38 \pm 0.076 \mathrm{~g}$ and $0.45 \pm 0.044 \mathrm{~g}$ for 3-week and 6-week body weight, respectively) than the corresponding values obtained by FUENTE \& SAN Primitivo (1985) for generations $1-8(0.08 \pm 0.32 \mathrm{~g}$ and $0.32 \pm 0.10 \mathrm{~g}$ for 3-week and 6-week body weight, respectively).

A positive correlated response in body weight has been generally obtained following divergent selection for first litter size (FALCONER, 1955 ; JOAKIMSEN \& BAKER, 1977) or selection for improved first litter size (BATEMan, 1966 ; EkLUnd \& BRADFord, 1977 ; EISEN, 1978). Changes in body weight as a result of selection for litter size have been generally moderate or small and only in a few cases a high correlated response was obtained (JOAKIMSEN \& BAKER, 1977 ; EISEN, 1978). Our results following selection for $T N Y-3$ seem to be similar to those obtained generally following selection for first litter size.

Received February 12, 1987.

Accepted September 16, 1987.

\section{References}

Bakker H., Wallinga J.H., Politiek R.D., 1978. Reproduction and body weight of mice after long-term selection for large litter size. J. Anim. Sci., 46, 1572-1580.

Barkley M.S., Bradford G.E., 1981. Estrous cycle dynamics in different strains of mice. Proc. Soc. Exp. Biol. Med., 167, 70-77.

Bateman N., 1966. Ovulation and post-ovulational losses in strains of mice selected for large and small litters. Genet. Res., 8, 229-241.

Beilharz R.G., Luxford B., 1981. Genetic improvement of reproduction. In : Proocedings of the 2nd Conference of the Australian Association of Animal Breeding and Genetics, Melbourne, February 20-23, 1981, 238-239, University of Melbourne, Victoria.

BradFord G.E., 1968. Selection for litter size in mice in the presence and absence of gonadotropin treatment. Genetics, 58, 283-295.

Bradford G.E., Barkley M.S., Spearow J.L., 1980. Physiological effects of selection for aspects of efficiency of reproduction. In : RoBerTson A. (ed.), Selection experiments in laboratory and domestic animals, 161-175, Commonw. Agric. Bur., Slough.

Dalton D.C., RaE A.L., 1978. The New Zealand Romney sheep : a review of productive performance. Anim. Breed. Abstr., 46, 657-680. 
EISEN E.J., 1978. Single-trait and antagonistic index selection for litter size and body weight in mice. Genetics, 88, 781-811.

EkLund J., Bradford G.E., 1977. Genetic analysis of a strain of mice plateaued for litter size. Genetics, 85, 529-542.

FALCONER D.S., 1955. Patterns of response in selection experiments with mice. Cold. Spring. Harbor Symp. Quant. Biol., 20, 178-196.

Falconer D.S., 1960. The genetics of litter size in mice. J. Cell. Comp. Physiol., 56, 153-167.

Fuente F., SAN Primitivo F., 1985. Selection for large and small litter size of the first three litters in mice. Génét. Sél. Evol., 17, 251-264.

Joakimsen O., Baker R.L., 1977. Selection for litter size in mice. Acta Agric. Scand., 27, 301-318.

Land R.B., Pelletier J., Thimonier J., Mauléon P., 1973. A quantitative study of genetic differences in the incidence of oestrus, ovulation and plasma luteinizing hormone concentrations in sheep. J. Endocrinol., 58, 305-309.

LUXFoRd B.G., BEILHARZ R.G., 1982. The effect of selection on reproductive performance early in life on lifetime performance. In: 2nd World Congress on Genetics Applied to Livestock Production, Madrid, October 4-8, 1982, volume 7, 479-482, Editorial Garsi, Madrid.

Matheron G., Poujardieu B., 1984. Expérience de sélection de la taille de portée chez le lapin. In : $3^{e}$ Congrès Mondial de Cuniculture, Rome, avril 4-8, 1984, volume 1, 66-78.

Ollivier L., 1982. Selection for prolificacy in the pig. Pig News Inf., 3, 383-388.

SCHÜler L., BüNGER L., 1982. Die Reproduktive Lebensleistung auf Fruchtbarkeit selektierter Labormauslinien. Arch. Tierzucht., 25, 275-281.

SkJERvold H., 1979. What about the genetic improvement of litter size ? Acta. Agric. Scand., Suppl., 21, 176-184.

VANGEN O., 1981. Problems and possibilities for selection for fecundity in multiparous species. Pig News Inf., 2, 257-263.

Wallinga J.H., BaKker H., 1978. Effect of long-term selection for litter size in mice on lifetime reproduction rate. J. Anim. Sci., 46, 1563-1571. 